\title{
Small Enterprise Affiliations to Business Associations and the Collective Action Problem Revisited
}

\section{Martina Battisti \& Martin Perry}

The objective of this study is to determine whether there is a consistent case for encouraging business representation through encompassing, sector-wide associations rather than narrowly constituted trade associations. The study draws on evidence from a large scale survey of SMEs in New Zealand to examine whether trade and sector associations attract different types of enterprise, the motivations for membership, the benefits obtained and how association membership can be made more attractive. Results suggest that each type of association appeals to a particular range of enterprises and that trade associations play a more diverse role than simply lobbying for a narrow constituency.

Key Words: Business association; New Zealand; collective action; network

JEL classifications: M10, R10

This is a post peer review, pre-copyedit version of an article accepted for publication in Small Business Economics (14-Aug-2014), which has been uploaded to one of the author's institution repository. Please check the journal's website for the final, proofread version. 


\section{Introduction}

Business associations are collective bodies intermediating between individual business action and state action (Bennett 1998). Reflecting this primary role, business associations have been examined mainly from the perspective of their role in lobbying for the interests of their members (Olson 1971; 1982; Aldrich 1999; Barnett 2006). Granovetter (1994: 455), for example, excludes business associations from a discussion of business groups that promote inter-firm learning on the grounds that their activities are principally about "negotiating and affecting the institutional and governance arrangements under which their industry proceeds'. Sabel (1994: 149) refers to the standard neo-liberal account of business associations as 'predatory lobbies using political pressure to extract returns they cannot achieve directly in the market'. A largely negative assessment of the role of business associations has arisen because the scope of lobbying supported by business associations tends to be restricted to interests shared among small groups of enterprises (Olson 1971; 1982). This is reflected in the continued preponderance of industry and trade-based business associations that frequently have a membership of fewer than 100 organisations (Aldrich 1999; Bennett 1998; Barnett 2006; Perry 2008). As a consequence, business associations have been characterised as predominantly acting as distributional coalitions that seek to advantage one group of interests by disadvantaging other groups that are either less well-organised or not organised at all (Olson 1971).

The fragmentation of business representation across multiple, narrowly constituted groups has also been linked to a chronic weakness of business associations (Bennett 2000; Barnett 2006). With small numbers of members, association secretariats command limited resources to provide service support because the effectiveness of collective representation depends on retaining representation of a large proportion of the industry represented (Bennett 1998). The public good nature of much lobbying activity means that membership is not necessarily 
required for industry participants to gain from the association's lobbying successes (Olson 1971; 1982; Bennett 1998). This context puts associations in a weak position to enforce membership rules that might enhance the ability of associations to generate membership benefits (Perry 2009). Measured by their level of participation and support for association activity, strong associations tend to depend on high levels of common interests among industry participants and high levels of organisation in the interests threatening the viability of industry participants (Barnett 2006). As a result of this fragmentation, the intensity and extent of the business networks fostered by formal business associations are considered weak and unlikely to be of significance to enterprise development.

A survey of 194 SMEs in Britain distinguished between different types of business associations including trade and professional associations, chambers of commerce and business clubs (Bennett and Ramsden 2007). The results suggest that SMEs expect a wide range of services to be delivered whatever the association they are affiliated with, but associations typically struggle to meet these expectations given the limited resources that they can command. In the context of a large scale survey of SMEs in Wales, Foreman-Peck et al. (2006) found a negative correlation between membership of a trade association and their measures of business performance. The finding is sensitive to the sectors included and exists alongside findings that investment in IT, skills and training or employing people is also unconnected to profitability. As the authors admit, examining the impact of trade association membership possibly needs more fine-grained evidence than they collected as membership of trade associations is high in mature sectors of the economy (Foreman-Peck et al. 2006). Nonetheless, the Welsh evidence fits with a tendency to dismiss business associations on the grounds that they are mainly involved in various forms of rent-seeking behaviour rather than in helping enterprises acquire competitive know-how (Perez-Aleman 2003). 
A contrasting assessment of the significance of business associations to enterprises arises when they are approached from the perspective of network theory. By providing access to complementary assets, additional sources of knowledge and third party endorsement, networks can help to resolve endemic challenges for small enterprise (Perry 1995). The extent of help received will vary according to the attributes of the network joined and the particular needs of the enterprise joining the network (Baum et al. 2000). In relation to trade associations for example, Dalziel (2006) argued that they can make a significant contribution to their members because their activities are driven by the need of their members and because associations possess specialised knowledge not available from third party providers of business support. More importantly, associations facilitate connections between enterprises that otherwise would not have been made or at least not made without more search effort than is facilitated through the common membership of a trade association. This indirect role of trade associations can also explain why trade associations may not be recognised for their role in enterprise development. Dalziel (2006) suggests that enterprise managers tend to acknowledge the importance of the connections they build rather than the agency which facilitated the making of the connection. This finding is supported by more recent evidence from Germany showing that innovative milieu are created through the building of relational capital between groups of enterprises that share membership of some form of business association (Maennig and Ölschläger 2011) .

The existing discussion of business association therefore provides a mixed assessment of their significance. From the perspective that their primary role is in lobbying for member interests, the case for encouraging representation in pan-industry associations has been made. Encompassing, sector-wide associations are viewed as more likely to focus on issues of net economic benefit to society than are associations that represent the interests of comparatively small groups of enterprises (Olson 1971; 1982). Similarly, evidence that associations tend to offer a similar range of services whatever the capacity to deliver them can support a case for 
rationalising business participation in fewer, well-resourced associations. A different agenda is applied by the suggestion that small, trade-based associations may be particularly effective in facilitating business networks among sub-groups of their members. Determining which if any of these agendas merits most attention justifies further investigation of the motivations for business association membership and the comparative benefits claimed.

The research reported here distinguishes between two main types of business association: trade associations affiliated to a specific business activity; and sector associations that have a panindustry membership (Bennett and Ramsden 2007; Perry 2009). This division is emphasised as it covers the two most widely joined business associations and allows evaluation of the contrasting judgments around the role of business associations. By investigating whether the two types of associations attract different types of enterprise with regard to firm and performance characteristics and whether members claim different benefits according to the association joined, the objective of the study is to determine whether there is a consistent case for encouraging business representation through encompassing, sector-wide associations rather than narrowly constituted trade associations. Specifically, this paper addresses four research questions.

1. How do trade and sector association members differ from each other with respect to firm characteristics and performance?

2. What are the reasons why small enterprises have joined the business associations to which they are affiliated?

3. What are the benefits small enterprises receive from their membership in trade associations compared to sector associations?

4. What actions increase the attractiveness of membership for small enterprises that are members of trade associations compared to sector associations? 
The study draws on evidence from a large scale survey of SMEs in New Zealand that examines the membership patterns of different types of SME and that identifies potential recruitment and association development strategies that may be employed to increase the value of business association membership to SMEs. The discussion commences with an outline of the research questions addressed in the paper that are then addressed in two stages. First, a theoretical rationale for the study is provided that explains how business associations have been thought to resolve the collective action problem and why this has encouraged a negative assessment of business associations. It then draws on network theory to identify how industry and trade-based associations may have particular strengths in providing business support networks. Second, original survey evidence is presented. Sampling and survey methods employed in the study are described followed by a presentation of empirical findings, discussion and conclusions.

\section{Business associations as collective representations of member interests}

Typically business associations, whether affiliated to a specific business activity (here referred to as trade associations) or having a wider pan-industry membership (here referred to as sector associations) provide direct support to individual members alongside collective representation of member interests (Bennett and Ramsden 2007; Perry 2009). This overlap in activity is the origin of three main reasons for dismissing the role of business associations as agents of enterprise support.

First, the theory of unequal returns to lobbyists has encouraged a negative interpretation of the role of lobbying in society. It argues that groups lobbying for an interest from which they obtain direct benefit are more easy to form than are groups that are aligned with society as a whole that oppose the allocation of the benefit (Perry 2001: 57; Mabbett 1995). The gainers from the benefit can be a small group who individually may receive a large benefit while the losses are dispersed widely and are individually small. Although those disadvantaged are in a numerical 
majority the gainers have more incentive to lobby intensively. Olson (1971: 124; 1982: 46) captured this by his description of trade associations as 'distributional coalitions' that are focussed on advantaging their own members by restricting opportunities for economic interests that are less well organised. Enterprise participation in trade associations is therefore less desirable than representation through associations that encompass multiple industries (Olson 1971). The assumptions are that narrowly-based interests groups focus on expanding their own interests at the expense of others. In contrast, encompassing associations that represent the interests of all types of enterprise or at least a wide cross section of enterprises are forced to pursue more ambitious and socially beneficial strategies that aim to expand economic opportunities rather than merely advance the interests of a small group.

Second, where the focus of representation is on protecting or changing industry-wide conditions the benefits potentially generated by business associations are public goods accessible to non-members ('free riders') as well as association members (Olson 1971; 1982; Aldrich 1999). The challenge for associations is that the delivery of effective representation and lobbying services depends on the ability to claim representation of a large share of the industry or sector whose interests are at issue. A fundamental barrier to the building of inclusive associations has been claimed because the benefit obtained by 'free riding' increases with the value of collective activity (Bennett 2000: 19). General responses to this situation have been to restrict the scope of collective activity to interests that are specific to a comparatively small group of enterprises and to lower entry requirements and membership conditions (Perry 2009). As well it encourages associations to develop a suite of membership services that deliver individual benefits to members as a way of increasing the incentive to join and reduce the incidence of free-riding. This helps to maximise recruitment but can trap associations in a 'low capacity, low service' syndrome as the need to provide a broad range of services stretches the resources of the association and militates against associations developing a specific focus to 
their activity (Bennett 2000). Partly for this reason it is generally recognised that collective strategy aimed at advancing the position of an industry as a whole is much harder to organise than cooperation between groups of enterprises within industries (Aldrich 1999; Barnett 2006).

Third, the lobbying role of business associations tends to skew them toward the interests of large enterprises (Herrigel 1993). Within any industry, large enterprises may be prepared to underwrite group activity on the basis of their individual share of the collective gain (Olson 1971). While in theory large enterprises have the capacity to engage in their own lobbying, they can see benefit in representing their own interests as being shared by a larger group (Salisbury 1984; Barnett 2006). On the other hand, larger enterprises tend to see little value in the services such as business advice, market information or guidance with regulation as they can obtain this from their own internal expertise or external business consultants (Bennett 1996; Perry 2008). Small enterprises, in contrast, may welcome the individual support provided by an association but be less concerned with the representation services since their share of any collective gain is minor.

\section{Business associations as network facilitators}

According to network theory, networks can be described in relation to its structure, its embedded resources and purpose. Lin (2008) argues that networks only provide the necessary condition for access to and use of its embedded resources. It is the variations in network structure and purpose that determine the quantity and quality of its embedded resources and ultimately the value networks generate for their members. In relation to network structure, two arguments have been put forward. The structural hole argument (Burt 1992; Granovetter 1973) concludes that low density in a network creates holes in its social structure that create information and control benefits for those who are skilled in building the relationships that span those otherwise disconnected parts of a network by performing a brokerage role. Having weak 
relationships that span structural holes allow a higher volume of information that contains fewer redundancies because the broker reaches not only more sources, but more diverse sources of information. The closure argument (Coleman 1988; 1990), however, concludes that in a network with high density i.e. where everyone is connected to everyone else in the network, higher reliability means that information flow and quality improves. Further dense networks facilitate trust and norms by facilitating effective sanctions and protect individuals from exploitation. Depending on the network structure i.e. structural holes or closure the nature of the embedded resources is also different. In the case of network closure, resources tend to be similar as individuals have stronger ties with individuals who are similar to themselves (McPherson et al. 2001). This in turn affects the purpose of the network as similar resources predominantly allow for expressive action (Lin 2008) which focuses on preserving and maintaining existing resources. Instrumental action, in comparison, is better achieved with diverse resources which are more likely to be found in the outer layers of social relations where ties are less intense and networks less dense.

From the perspective of network theory, it can therefore be argued that business associations fulfil a role of enterprise support that goes beyond the collective representation of member interests. More specifically, the ways that business associations merit recognition are in: (i) giving member enterprises legitimacy with external parties; (ii) facilitating interaction through networking activity; (iii) performing a brokerage role bridging previously unconnected parties; (iv) facilitating joint action through network closure (Dalziel 2006).

(i) Membership of an association can give legitimacy to an enterprise as in the way that trade associations representing building and property maintenance service companies may endorse the performance of association members through some form of service guarantee. Trade associations are differentiated by the extent to which they establish membership eligibility rules 
and enforce adherence to industry codes of practice but they typically aspire to encourage high standards of commercial behaviour (Bennett 1998; Perry 2008). Of course, having a large customer as a client provides small enterprises with a form of legitimacy too but such endorsement is not open to all enterprises and may not exist for those serving other small businesses and individual consumers.

(ii) It has long been argued that the intensity and extent of the business networks fostered by business associations are weak and unlikely to be of significance to enterprise development (Bennett and Ramsden 2007; Curran and Blackburn 1994). The resources commanded by association secretariats and the extent of their formal activities such as the range of membership services offered are, however, incomplete measures of the significance of businesses associations. Membership of business association gives access to network building opportunities and informal interaction at membership gatherings as well as access to the formal services provided by the secretariat such as access to management advice, market information and assistance in complying with business regulation (Barnett 2006).

(iii) According to Dalziel (2006) the significant contributions of business associations in facilitating innovation can be overlooked because their role is primarily that of a broker that provides mechanisms through which enterprises can share knowledge, engage with other enterprises and be motivated to emulate the achievements and strategies of their peers. These roles are undervalued partly as individual enterprises tend to identify the private and economic contributions of customers and suppliers as having most impact on their ability to innovate, overlooking the importance of the intermediary in enabling the connections to be developed. In a similar way, McDermott et al. (2009) argue that networks should be judged not simply by the number of connections that they offer but by the extent to which they include bridges to other producer communities and additional knowledge sources. 
(iv) In relation to network closure it can be argued that trade associations have a particular strength in bringing together all relevant industry participants within the reach of a single network. One measure of this is that trade associations frequently claim to represent over 70 percent of the targeted membership, as shown in studies of trade associations in Australia, Ireland and New Zealand (Perry 2008; 2009; 2012). Network closure reduces the risk of incomplete communication and facilitates sanctions against non-conforming actors (Coleman, 1988). A high degree of closure is directly relevant to collaborative activities in which firms work together to develop or build upon a common technological platform (Dalziel 2006). Beyond specific technological projects, industry-wide collaboration facilitates informal agreement over the norms of competitive behaviour and the development of what regional geographers and economists call 'untraded interdependencies' encompassing flows of tacit knowledge, technological spillovers, trust-based business relationships and shared values (for example see Storper and Scott 2009).

In summary, from the perspective of network theory, the role of business associations can be described as providing legitimacy, enabling innovation and building innovative milieu rather than supporting innovation directly (Dalziel 2006; Maennig and Ölschläger 2011).

\section{Research propositions}

As indicated in the previous section, the empirical evidence on the role of business associations for SMEs is inconclusive. While some research indicates that business associations can contribute to the innovation potential (Dalziel 2006) and competitive strength of small enterprises (Maenning and Ölschläger 2011) others argue that business associations are too weak to have a significant positive impact (Curran and Blackburn 1994). One reason for the inconclusive results is that business associations have predominantly been researched as a homogenous group and little attempts have been made to differentiate between different types 
of business associations. As indicated in the previous section business associations are highly variable in their purpose, levels of support and membership motivations. We contribute to the literature by distinguishing between trade and sector associations recognising that each may have a particular importance to their members. The inconclusive results that have been obtained in past research may at least in part be explained by the lack of differentiation on the side of the members. The membership base of business associations is potentially diverse and heterogeneous and business associations might not only attract different types of firms, but deliver different benefits across their different types of members. For this reason we include firm and performance characteristics in our assessment of business associations' affiliation. Based on the theoretical considerations in the previous section, four research propositions have been developed:

\section{Small enterprises that affiliate with trade associations have got different firm and} performance characteristics compared to those affiliating with sector associations. Evidence that particular types of small enterprise tend to be members of an association may indicate how they serve some interests comparatively well. If there is no discernible difference in the kinds of enterprise belonging to business associations this points to membership being an outcome of the priorities of individual managers rather than the way associations are valued by particular types of enterprise. A difference in the relative performance of association members is a further dimension of association focus: whether associations tend to attract underperforming enterprises that are in search of business support or whether associations tend to attract high performing enterprises, possibly because they are meeting unfamiliar challenges, business managers are confident to share experience with their peers or more exercised by the opportunities or impediments arising from government regulation.

2. The motivations that small enterprises have for affiliating with a trade association are different compared to those affiliating with a sector associations. As discussed earlier, a feature 
of most industrial economies is the continuance of both forms of representation - trade and sector - despite duplication in the main roles that are performed by each type of association and differences in the capacity to deliver the same bundle of services. Evidence that enterprises have particular reasons for joining the type of association that they have suggests that strategic decisions are made affecting the choice of association. The ability to exercise a strategic choice indicates that associations focus their activity to meet the preferences of their particular member group. From the perspective of small enterprises this would mean that despite similar service offerings associations are differentiated in other ways.

3. The benefits that small enterprises receive from their membership in trade associations are different from the benefits small enterprises receive from their membership in sector associations. As indicated earlier, previous research has tended to dismiss the informal contributions of business associations to the development of untraded interdependencies. Identification that networking and other informal activities are important drivers of membership and membership satisfaction supports increased importance being attached to the contribution of business associations to SMEs. Evidence of different types of associations generating different benefits for members may indicate the value of maintaining association variety. This further question recognizes that the actual benefits obtained from membership may differ from the expected benefit that motivated the original membership. For example, a SME may join an association in response to a particular business issue which once resolved changes the use made of the membership. This is possible given a potentially long period of membership and a change in business performance post joining. Motivations may differ from benefits too where membership arises from loyalty to the industry and a wish not to be viewed as a 'free rider' while actual membership delivers some additional, tangible outcomes for the business. 


\section{Depending on the type of membership, small enterprises identify different actions that would}

increase the attractiveness of trade compared to sector associations. As noted above, the main distinction between associations is the breadth of membership solicited and the scope of the lobbying activity engaged upon. Both main types of association provide a similar range of services because enterprises favour being able to access a bundle of services from a single point of entry rather than engaging with multiple specialised agencies. Nonetheless, some specialisation emerges as the scope of the lobbying affects the focus of aligned services. The value of association services is enhanced through their provision alongside other roles. For example, trade associations are in a stronger position than sector associations to provide accreditation of members such that the association can claim to represent businesses conforming to an industry code of practice. For a trade association, accreditation schemes are a way to minimise the risk of free rider behaviour by combining actions that generate collective benefits (lobbying government agencies) with services that generate individual benefits (being recognised as an accredited provider of a product or service). For the sector association, the large but widely drawn membership suits the provision of generic business support such as industrial relations advisory service. For these reasons it remains relevant to examine whether a particular constituency of enterprises is drawn to one type of association over the other.

\section{Survey Sample and Method}

The current study is part of the 2010 BusinesSMEasure postal survey of SMEs in New Zealand conducted annually by the New Zealand Centre for SME Research (2011). The study follows SME definitions that have been recommended for New Zealand: micro firms with up to five full-time equivalent staff numbers (FTE); small firms with six to 49 FTEs; and medium-size firms with 50 to 99 FTEs (Cameron and Massey 1999). As of 2010, there were 474,415 SMEs in New Zealand (Ministry of Economic Development 2010). Of these, 89.7 percent were micro-sized, 9.3 percent were small and one percent was medium-sized. With respect to 
industry, 31 percent represent the manufacturing sector (including construction) and 69 percent the services sector (including wholesale and retail, business, finance and property and other services).

The sample drawn is a stratified random sample of SMEs in New Zealand with equal numbers of respondents in firm size strata of zero to five employees and six to 49 employees. Similarly, the sample comprises equal representation of manufacturing and service enterprises including a spread of sub-sectors within each major sector. The sampling strategy was chosen to allow comparison of important SME size groups and industry sectors.

The data used in this study was derived from the Martins database, a commercial provider of business-to-business information in New Zealand. Martins offers the largest and most comprehensive business database in New Zealand that is constantly updated and offers a range of selection criteria.

The survey was sent to 4,222 firms and obtained 1,838 usable responses. The response rate of 43 percent is well above the average response rate of 27 percent involving studies of small firms (Bartholomew and Smith 2006).

While the data relate specifically to New Zealand, Bennett and Robson (1999) suggest that the pattern of relationships between advisors and firms are similar across different countries. This is confirmed by Perry $(2009 ; 2012)$ who found that New Zealand has a population of trade associations that are similar in their representation of industry and levels of support as those in other industrial economies. There is both a high representation of business activity through trade associations and high levels of membership from among the businesses targeted. Membership density tends to be highest for associations representing industries dominated by large enterprises. In areas where small enterprises are numerically concentrated such as restaurants, retailing and building trades association membership can drop to a third or less of 
the potential recruitment whereas in areas where the potential membership is a comparatively small group of medium to large enterprises membership density frequently rises to over two thirds (Perry 2008). The generalizability of results, nevertheless, has to be treated with caution, as there are macro-institutional factors that vary across countries that might impact on the role of business associations for SMEs. For example, in a small economy such as New Zealand an absence of regional and cultural variation has been suggested to facilitate engagement in business associations due to the absence of intervening connections (see Perry 2012).

The survey investigated membership of two types of business association: sector associations (i.e. chamber of commerce and employer associations) and trade associations. With respect to each type of association, responses ranged from $1=$ currently a member, $2=$ not currently a member but have been in the last 5 years to $3=$ not a member for at least six years or longer. Eight items were used to measure the motivation for joining an association (see Table 5), seven items to measure the benefits perceived to be obtained (see Table 6) and eight items to measure actions to increase the attractiveness of association membership (see Table 7). All items were measured on five point Likert scales.

Five enterprise characteristics were captured: (i) firm size (measured by full-time equivalent staff numbers); (ii) main market (measured using 1=local/regional, $2=$ national to 3=international); (iii) industry affiliation (categorising businesses into $1=$ =manufacturing, $2=$ construction, $3=$ wholesale/retail, $4=$ business, property and financial services and $5=$ other services); (iv) type of location (1=urban and 2=rural); (v) firm age (years).

Firm performance is difficult to measure because it is a multidimensional, complex and subjective phenomenon (Achtenhagen et al. 2010). In examining the difference between trade and sector association members, it would be desirable to have some measure of long term performance to establish whether one type of association attracts more dynamic enterprises. In 
small enterprise research, however, it is difficult to obtain organisational records such as balance sheets and profit and loss statements. Business owners tend to be reluctant to share records or report accurate financial data in a postal survey. This situation led to the measurement of perceived performance as advised by Garg et al. (2003). Further, crosssectional studies are only able to capture performance snapshots rather than variations and patterns over time. As the global financial crisis has resulted in changing market conditions for small firms, we expected to find considerable variation in the performance of firms. But again, data on actual changes of firm performance is difficult to obtain. As a result, we used four measures to operationalize firm performance: turnover, profitability, market share and productivity. For each of these measures, respondents were asked to assess the firm's current performance to that 12 months ago using a five-point Likert scale $(1=$ strongly increased to $5=$ strongly decreased).

As a further aspect of enterprise performance, four measures of innovation recommended in the Oslo Manual (OECD 2005) are measured. These items ask respondents to indicate whether they have developed or introduced new or significantly improved products or services, operational processes, organisational or managerial processes, and sales or marketing methods in the last 12 months $(1=$ yes, $2=$ no). The four measures are focused on innovation output rather than input or process and are an incomplete measure of a firm's innovation activity. They do, however, measure different types of innovation that are particularly relevant for the SME sector.

In line with a recommended test for non-response bias in this type of survey (Armstrong and Overton 1977) four demographic profile variables were examined (gender, firm size, legal form of firm and family firm). Respondents and non-respondents were not significantly different across these variables suggesting that non-response bias is not affecting the survey results. To examine whether results are affected by common method bias (arising where a single 
instrument to measure all the variables is used), Harman's single-factor test was performed on selected items (Podsakoff et al. 2003). The un-rotated factor solution found seven underlying factors with eigenvalues greater than one. These seven factors accounted for variances ranging from 1.46 percent to 20.8 percent and no factor accounted for more than 50 percent of the total variance. This form of common method bias detection is rather weak but it gives some evidence that a common method bias is not affecting responses to the questions. Pearson Chi-Square, Student-t test and ANOVA were used to compare variations between the population subsets of interest to the study.

Studies in relation to the use of external business advice by SMEs are prone to self-selection bias, as enterprises tend to self-select themselves for assistance (Wren and Storey 2002; Bennett, Robson and Bratton 2001). Particularly business associations consist predominantly of firms that chose to be members (Bennett and Robson 1999) suggesting that SMEs make strategic decisions when it comes to the choice of association types. It can be argued that firms chose the types of associations that they perceive as generating the greatest benefits. The results of this study therefor allow no conclusions about the impact different types of business associations have on small enterprise development. Instead the contribution of this study is to examine the differences in the membership base of trade compared to sector associations, the motivations for joining, the perceived benefits obtained from the membership as well as the actions that contribute to increased attractiveness of the membership.

\section{Business association membership in New Zealand}

With regard to enterprise characteristics 52.2 percent of firms are micro enterprises (with up to five FTE employees); 44.1 percent are small firms (with six to 49 FTE employees) and 3.6 percent are medium-sized enterprises with over 50 FTEs. Most firms are mature and well established with an average age of 26 years. All sectors of the private sector economy are 
represented: manufacturing firms provide 35.1 percent of responses, construction 11.5 percent, the wholesale or retail sector 21.7 percent, business, finance and property services 10.3 percent and other services 21.4 percent.

SMEs and business associations. Overall the survey found that 60.4 percent of SMEs are members of a business association. Business association members comprise those belonging solely to a trade association (43.8 percent), solely to a sector association (21.1 percent) and those with membership of two or more types of association ( 35 percent). Of the 39.6 percent of non-members, those who have no membership experience in the last five years or have never been members (62.2 percent) outnumber those who have lapsed membership over this period (37.8 percent). This relatively high lapse rate may indicate that some businesses join an association simply to help resolve an individual issue rather than for any wider motivations. Particularly with respect to large trade associations (for example, those representing retailers, restaurant owners or building trades), association executives report a tendency for SMEs to join when they are looking for assistance with a business problem and lapse once the issue has been addressed (Perry 2008). To reduce this problem, some associations put a cap on the amount of free individual advice that can be accessed annually by individual members and generally there no signing-on incentives that might induce membership hopping. The high lapse rate might also be a reflection of the difficult economic conditions faced by enterprises. Particularly enterprises that join business associations to gain legitimacy might be more likely to terminate their membership in times of austerity. Overall, however, it appears that most association members have a long term commitment to their association. To build up a profile of those enterprises that join trade associations compared to sector associations, we had to exclude firms with multiple memberships from further analysis. This allowed us to investigate two distinctly different membership types. 
--- Insert Table 1 about here ---

Firm characteristics and performance. Results show that the profile of SMEs that are exclusively members of a trade association differs from those that are exclusively members of a sector association (Table 2). Enterprises from urban areas seem more likely to affiliate with sector associations. While 86.1 percent of respondents from urban areas affiliate with a sector association, only 71.5 percent affiliate with a trade association. This corresponds with the findings that trade associations appear to be more attractive to SMEs that serve a local or regional market. This group of enterprises makes up 72.2 percent of trade association members compared to only 50.5 percent of sector association members. With respect to industry, sector associations seem to be more attractive to manufacturers. With 46.6 percent of enterprises, manufacturers make up the largest industry that affiliates with sector associations. A further point of difference is that the recruitment of larger SMEs (employment of 6 or more) increases in the case of sector associations. In contrast, trade associations are successful in recruiting micro enterprises employing 5 or fewer and firms. While 57.7 percent of trade association members were micro in size, only 33.3 percent of sector associations were micro in size. In contrast, 62.4 percent of sector association members were small in size compared to 40 percent of trade association members. Age of the enterprise has no significant impact on the type of membership with the vast majority of members in both types of associations being 5 years or older.

--- Insert Table 2 about here ----

With respect to financial performance, findings reflect the impact of a slowing economy with respondents indicating rather stable performance across the four performance measures. It is worth noting, however, that enterprises belonging to sector associations seem more likely to outperform enterprises affiliating with trade associations. They are more likely to have 
increased their turnover and productivity and are more likely to have introduced new products or services, organisational or marketing innovation in the last 12 months.

--- Insert Tables 3 and 4 about here ----

Motivations for membership. There is evidence that membership selections are based on specific motivations (Table 5). Both types of association attract members for a diversity of reasons indicating that no type of association is perceived as monopolising any particular role. Trade associations are favoured for their role in providing opportunities to learn from other members (ranked first), as an expression of industry loyalty (ranked second), to gain access to individual advice and to achieve representation to government (ranked third and fourth respectively). In comparison, access to individual advice is the most important motivation for SMEs to join a sector association. It is also the only motivation that is rated as more important by sector association members than by trade association members. The strongest point of difference why SMEs join trade associations compared to sector associations is because of loyalty to the industry (ranked second and seventh respectively). Social opportunities is the least important motivation for SMEs across both types of associations.

--- Insert Table 5 about here ---

Membership benefits. The highest benefits SMEs receive are the same across both types of business associations: improved awareness of industry issues and improved ability to cope with problems. The least benefits SMEs receive are also similar for both types of associations: reduced business costs and improved access to potential business partners. While the ranking of perceived benefits is very similar for both types of associations, the extent of benefit reported varies considerably. More specifically, members of trade associations are more likely to report a higher benefit in relation to improved awareness of industry issues, reduced business costs, 
improved motivation to grow the business, improved access to customers and potential business partners (Table 6).

--- Insert Table 6 about here ---

Improving associations. Again, similarities emerge in relation to how SMEs rank the actions that they consider to be important to increase the attractiveness of association membership (see Table 7). The actions that are of most importance for trade as well as sector association members are more government lobbing and more small firm focus. The actions of least importance are more influence on the association's activity and less big firm focus. For both types of members, however, access to individual advice is more likely to raise interest in membership than is an increase in networking opportunities. A significant difference between trade and sector association members was found for only two actions. Trade association members favour more guidance over regulatory requirements. They also seek more opportunity to influence association activities, despite attaching comparably low importance to this action compared to other actions.

--- Insert Table 7 about here ---

\section{Multivariate analysis of differences between SME that are trade or sector association members}

Logistic regression was performed to estimate the effects of firm and performance characteristics, motivations for membership, membership benefits and actions suggested for improving membership on the likelihood that enterprises belonged to a sector association (coded 1) compared to a trade association (coded 0 ). Only those variables were included as independent variables that had previously been identified to significantly differentiate between the two types of membership. To detect outliers, standardised residuals were inspected and 17 cases were removed if they were greater or less than $+/-2.58$. Further, 25 cases were excluded 
due to missing values. Logistic regression uses maximum likelihood estimation which relies on large-sample asymptotic normality which means that reliability of estimates declines when there are few cases for each observed combination of independent variables. The 680 remaining cases available for the analysis satisfied the recommended sample size by Hosmer and Lemeshow (1989). Further, correlation coefficients and VIF values (VIF < 3) were inspected and no multicollinearity was detected. The logistic regression was statistically significant, $\chi 2$ $(25)=314.607, p<.000$. The model explained 61 percent $\left(\right.$ Nagelkerke $\mathrm{R}^{2}$ ) of the variance in membership and correctly classified 86 percent of cases. The criterion used to determine classification accuracy was that the observed hit rate had to be 25 percent higher than the proportional by chance hit rate. Overall, the model was considered to adequately fit the data.

--- Insert Table 11 about here ---

The results of the logistic regression indicate that there are a comparatively few variables in our study that make it more likely an enterprise joins a sector association than a trade association. Nonetheless those variables that do differentiate members are consistent with associations playing different roles for their members. In relation to firm characteristics and performance results showed that sector association members were more likely to be at the larger end of the firm size spectrum and more likely to belong to the manufacturing sector. They were also more likely to have increased productivity and have introduced a new product within the last 12 months.

Enterprises that were members of sector associations were less likely to have joined the association to give the business status or to express loyalty to the industry. Instead they were more likely to have joined to be represented to government and to get access to individual advice. Further, members of sector associations were less likely to benefit from reduced business costs and improved awareness of industry issues, but they were more likely to benefit 
from improved motivation to grow the business and improved access to potential business partners. No differences were found in relation to actions that would improve the attractiveness of trade compared to sector associations.

\section{Implications of the survey evidence}

With respect to the first research question, findings confirm that the membership base of business associations is very diverse and that different types of associations attract different types of enterprises, particularly in relation to size, sector and performance. With more frequent participation in product innovation and a higher likelihood of increased productivity, members of sector associations appear to be more strongly performing SMEs than trade association members. It can be argued that the discernible difference in the type of enterprises belonging to trade and sector associations indicates that associations have specific strengths that serve a particular enterprise segment comparatively well.

With respect to the second question addressed by the survey, there is evidence that SMEs participating in trade associations have different motivations compared to SMEs participating in sector associations. Members of sector associations were more likely to have joined to get access to individual advice which might reflect the growing complexity and the unfamiliar challenges growth and innovation orientated enterprises might face. The evidence in the survey does not allow this to be confirmed and other explanations may exist that would also require further investigation. It may reflect, for example, how the enterprise choses a sector association over a trade association as its activity falls outside the core activity represented by a trade association or how the enterprise does not share an agenda pursued by the trade association. More importantly, however, findings indicate that membership of a trade association is driven by a range of motivations including status in the market and loyalty to the industry and that representation to government is less important to trade association members compared to sector 
association members. This suggests that trade associations play a more diverse role than simply lobbying for a narrow constituency and questions their depiction as distributional coalitions.

Turning to the third survey question, respondents agreed that improved awareness of industry issues is an important benefit received from business associations in general, but members of sector associations attribute significantly less importance to it compared to members of trade associations. This finding is consistent with UK evidence in indicating the greater frequency of 'soft' outcomes (such as improved awareness of issues and more ability to cope with challenges) than 'hard' benefits (reduced business costs) (Bennett and Ramsden 2007). Further, it supports the notion that members of trade associations are particularly concerned to obtain industry-specific support possibly including the ability to understand trends going on in their industry. The ability to gain insight into what larger companies are doing in their industry may be particularly sought. Members of sector associations, on the other hand, perceive to get a higher benefit from an improved motivation to grow the business and improved access to business partners. This reflects to some extent the finding that different types of associations attract different types of enterprises because they address specific needs comparatively well. The fact that different types of associations generate different benefits for members indicates the value of maintaining association variety.

In relation to the fourth survey question, SMEs tend to join associations for various member benefits as well as to support representational activity. Going forward association members generally support associations maintaining a diversified service offering that includes more lobbying and more individual advice. As in the UK (Bennett and Ramsden 2007), SMEs appear to be broadly satisfied with the bundling of association services to encompass member, club and collective benefits and do not express a demand for greater specialisation between business associations. The finding that members favour the continuance of a broad service offering is important to recognise since business associations are frequently criticised for their provision 
of overlapping services rather than for narrowly concentrating on areas of strength. An explanation for this is that businesses see a benefit in associations combining the delivery of individual and collective benefits recognising that where associations focus on lobbying alone (the principal source of collective benefit) the risk of free riding increases unless lobbying is directed at concerns that are widely shared and strongly felt among the potential members of the association. A further explanation for the preference to see associations maintain their existing bundle of services is the high cost that would be associated with establishing new groups purpose-designed for the contemporary business environment. Forming a new association requires effort to search for and recruit potential members, agree association rules and a formal constitution, negotiate a programme of activity and secure the resources to carry out this activity. This provides a further reason for increasing the understanding of the contributions made by business associations as there is frequently a strong tendency for public agencies that need to work with the business community to seek to develop new groupings rather than work with already established associations.

The larger issues addressed by the study are the implications of these findings for the perceived desirability of a shift toward business participation in encompassing sector associations rather than narrowly constituted trade associations and whether the evidence justifies a reappraisal of business association activity. From the perspective of the contribution of business associations as network facilitators, the findings in this study do not support any move to encourage participation in sector over trade-based associations. The evidence in the survey is consistent with the importance of network closure and legitimacy as reasons why business associations are valued, as proposed by Dalziel (2006). The result that business status is a less important motivation for joining sector associations that trade associations, reflects how trade associations typically seek to promote membership as a form of third party endorsement (Perry 2008). The importance of network closure has not been directly measured in the study except 
in so far as the perceived opportunity to learn from other members is related to the extent of network closure. Access to parties who can be learnt from is a partial indicator of the extent of network closure and it is the motivation the received the highest ranking from trade associations members. Clearly, there is scope for future research to directly investigate the occurrence of the network advantages identified by Dalziel (2006) as important, but these mechanisms do offer some theoretical support for the empirical findings in the study.

The finding that sector associations attract growth-orientated enterprises and that they are judged to be of some value in assisting this ambition may suggest support for encouraging business participation in sector over trade associations. That agenda arises from the assumption that sector groups focus their lobbying activity on broader issues than narrowly constituted trade associations so that successful lobbying advances economic performance across the economy and not simply for one group of enterprises at the expense of another group. Contrary to such an agenda is the greater diversity of motivations explaining membership of a trade association than a sector association that extend beyond lobbying. Rather than an agenda of favouring one type of association over another it may equally be argued that our evidence support encouragement of the enterprise development support potentially provided by trade associations. It also suggests that business associations may be well advised to demonstrate their value as network facilitators as a way of encouraging greater recognition of their contributions to enterprise development and innovation.

In this regard guidance exists from the study of trade associations in newly industrialising economies as to how they can be encouraged to play a role in enterprise development. PerezAleman (2003) identifies a process through which trade associations cease to be rent seeking entities to take on developmental roles that enhance the competitive capabilities of all members and benefit the economy as a whole. This is achieved where associations engage in goal setting and the pursuit of new standards of productivity through a process of information exchange 
and knowledge sharing. Such a process fits with Sabel's (1994) concept of 'learning-bymonitoring' whereby economic actors participate in a self-sustaining learning process in which individual enterprises set common performance goals and share their experience in meeting those targets. Perez-Aleman (2003) identifies such a learning-by-monitoring phenomenon in the case of the tomato processing industry in Chile. The context was an export-orientated sector that needed to upgrade its technological and food safety processes to meet the requirements of overseas markets. Whether the same opportunities exist for industries in older economies without the possibility of pursuing market growth on the same scale is unclear. Nonetheless it points to a broad strategy for incorporating trade associations with industry development policy based around the setting of standards and benchmarks, identifying shortfalls against current performance and sharing experience to assist the productivity of the industry as a whole.

The focus of this study has been on the difference between trade and sector associations but it is important to recognise that trade associations vary in their size and purpose. It is well established that those associations potentially representing a diverse constituency in terms of business characteristics face a greater organisational challenge than those representing a homogenous group of enterprises (Barnett 2006; Donar and Schneider 2000). At the same time those associations with a diverse membership have potential to be the most important in terms of their capacity to act as network intermediaries. On these grounds future research is recommended to give particular attention to developing greater understanding of the roles played by trade associations that represent a diverse business constituency.

\section{Conclusion}

Findings from this study suggest that there is no immediate case for seeking to concentrate business representation into fewer sector-based associations. First, associations differ in their membership profile in terms of enterprise and business performance characteristics, suggesting 
that each type of association appeals to a particular range of enterprises. Second, membership of a trade association is driven by a range of influences as well as by the demand for representation to government, suggesting that trade associations play a more diverse role than simply lobbying for a narrow constituency. Previous research has tended to dismiss their role as agents for informal knowledge sharing but the survey evidence indicates that the opportunity to learn from other members is the single most frequent motivation for joining trade associations. The desire to express loyalty to an industry emerges as another motivation for trade association membership and this also suggests a role for associations in supporting personal affiliations and maintaining goodwill among industry participants. Third, the study challenges the depiction of business associations as being largely weak and ineffective. A high proportion of members claim tangible benefits from their association membership. Additional 'soft' benefits such as an increased awareness of industry issues are significant outcomes too. While it is not possible to judge the precise importance of these outcomes they may add to an owner manager's confidence and help sustain SMEs through troubling economic conditions. The spread of these outcomes to enterprises in comparatively rural and isolated locations where direct access to other sources of business support may be restricted adds to underline the important contribution of trade associations even when this is not translated into 'bottom line' gains. Fourth, improving the quality of business service offerings would not enhance the attractiveness of sector associations more than trade associations.

An important implication of the study is that public agencies should recognise trade and sector associations as potentially useful agents for supporting economic development strategies. In New Zealand there has been a tendency for SME support programmes to shun involvement of existing business associations in preference to starting new groups. The relationship between business associations and government can be difficult because they are partly engaged in representing business concerns against public policy measures. 


\section{References}

Achtenhagen, L., Naldi, L., \& L. Melin, L 2010. 'Business growth: do practitioners and scholars really talk about the same thing?', Entrepreneurship Theory and Practice, 34(2), 289-316. DOI: 10.1111/j.1540-6520.2010.00376.x

Aldrich, H. 1999. Organizations Enabling. San Francisco: Sage.

Armstrong, J. S., and T.S. Overton 1977. 'Estimating non-response bias in mail surveys,' Journal of Marketing Research, 14, 396-402. DOI: 10.2307/3150783

Barnett, M. 2006. 'Finding a working balance between competitive and communal strategies,' Journal of Management Studies, 43(8), 1753-73. DOI: 10.1111/j.14676486.2006.00661.x

Bartholomew, S. and A. Smith 2006. 'Improving survey response rates from chief executive officers in small firms: The Importance of social networks,' Entrepreneurship Theory and Practice, 30(1), 83-96. DOI: 10.1111/j.1540-6520.2006.00111.x

Baum, J.A.C., Calabrese, T., \& Silverman, B.S. 2000. 'Don't go it alone: Alliance networks and startup performance in Canadian biotechnology'. Strategic Management Journal, 21(3), 267-294. DOI: 10.1002/(SICI)1097-0266(200003)21:3<267::AIDSMJ89>3.0.CO;2-8

Bennett, R. 1996. 'Can transaction cost economics explain voluntary Chambers of Commerce,' Journal of Institutional or Theoretical Economics, 152(4), 653-80

Bennett, R. 1998. 'Business associations and their potential contribution to the competitiveness of SMEs,' Entrepreneurship and Regional Development, 10(3), 243-60. DOI: $10.1080 / 08985629800000014$

Bennett, R. 2000. 'The logic of membership of sectoral business associations,' Review of Social Economy, 58(1), 17-42. DOI: 10.1080/003467600363093

Bennett, R. and M. Ramsden 2007. 'The contribution of business associations to SMEs: strategy, bundling or reassurance?' International Small Business Journal, 25(1), 49-76. DOI: $10.1177 / 0266242607071781$

Bennett, R. and P. Robson 1999. 'The use of external advice by SMEs in Britain,' Entrepreneurship and Regional Development, 11(2), 155-180. DOI: 10.1080/089856299283245

Bennett, R., Robson, P. \& Bratton, W. 2001. 'The influence of location on the use by SMEs of external advice and collaboration,' Urban Studies, 38(9), 1531-1557. DOI: $10.1080 / 00420980126671$ 
Burt, R. 1992. Structural holes: the social structure of competition. Cambridge, MA: Harvard University Press.

Cameron, A, and C. Massey 1999. Small and medium-sized enterprises: A New Zealand perspective. Auckland, New Zealand: Addison Wesely.

Coleman, J. 1988. 'Social capital in the creation of human capital', American Journal of Sociology, 94, 95-120.

Colema, J. 1990. Foundations of social theory. Cambridge, MA: Harvard University Press.

Curran, J. and R. Blackburn 1994. Small Firms and Local Economic Networks: The Death of the Local Economy? London: Paul Chapman.

Dalziel, M. 2006. 'The impact of industry associations'. Innovation: Management, Policy and Practice, 8(3), 296-306. DOI: 10.5172/impp.2006.8.3.296

Doner, Richard F. and Ben R. Schneider. 2000. 'Business associations and economic development: Why some associations contribute more than others.' Business and Politics, 2(3), 261-288. DOI: 10.1080/713991579

Foreman-Peck, J., Makepeace, G. \& Morgan, B. 2006. 'Growth and profitability of small and medium-sized enterprises: Some Welsh evidence'. Regional Studies, 40(4), 307-319. DOI: $10.1080 / 00343400600725160$

Garg, V., B. Walters and R. Priem 2003. 'Chief executive scanning emphasis, environmental dynamism and manufacturing performance', Strategic Management Journal, 24(8), 724-744. DOI: $10.1002 / \mathrm{smj} .335$

Granovetter, M. 1994. 'Business groups', in The Handbook of Economic Sociology. Eds N. Smelser and R. Swedberg. Princeton, NJ: Princeton University Press.

Granovetter, M. 1973. 'The strength of weak ties,' American Journal of Sociology, 78, 13601380.

Herrigel, G. 1993. 'Large Firms, Small Firms, and the Governance of Flexible Specialisation: The Case of Baden Württemberg and Socialized Risk,' in Country Competitiveness: Technology and the Organizing of Work. Ed. B. Kogut. New York: Oxford University Press.

Hosmer, D. and Lemeshow, S. 1989. ‘Applied Logistic Regression'. 2nd ed., 2000. NY: Wiley and Sons.

Lin, N. 2008. 'A network theory of social capital,' in The handbook of social capital. Ed Castiglione, D., Van Deth, J. \& G. Wolleb. Oxford University Press.

Mabbett, D. 1995. Trade, employment, and welfare: A comparative study of trade and labour market policies in Sweden and New Zealand, 1880-1980, Oxford: Clarendon Press. 
Maennig, W. and M. Ölschläger. 2011. 'Innovative milieu and regional competitiveness: the role of associations and chambers of commerce and industry in Germany,' Regional Studies, 45 (4), 441-452. DOI: 10.1080/00343401003601917

McDermott, G., Corredoira, R. and Kruse, G. 2009 'Public-private institutions as catalysts of upgrading in emerging market societies', Academy of Management Journal, 52(6), 12701296. DOI: 10.5465/AMJ.2009.47084929

McPherson, M., Smith-Loving, L. \& J. Cook 2001. 'Birds of feather: homophily in social networks,' Annual Review of Sociology, 27, 415-234.

Ministry of Economic Development 2009. SMEs in New Zealand: Structure and dynamics 2009. Wellington, New Zealand: Ministry of Economic Development.

New Zealand Centre for SME Research 2011. Business Measure Summary. Wellington, Massey University: NZCSMER.

OECD 2005. Oslo Manual: Guidelines for Collating and Interpreting Innovation Data. Paris: OECD.

Olson, M. 1971. The Logic of Collective Action: Public Goods and the Theory of Groups. Cambridge MA: Harvard University Press.

Olson, M. 1982. The Rise and Decline of Nations: Economic Growth, Stagflation, and Social Rigidities. New Haven: Yale University Press.

Perez-Aleman, P. 2003. A Learning-centered view of business associations: Building business-government relations for development, Business and Politics, 5(2), 193-221. DOI: $10.1080 / 1369525032000125385$

Perry, M. 1995. Small Firms and Network Economies. London: Routledge.

Perry, M. 2001. Shared Trust in New Zealand. Wellington: Institute of Policy Studies.

Perry, M. 2008. 'Trade associations: a case of Cinderella at the ball?', University of Auckland Business Review, 10(2), 54-62.

Perry, M. 2009. 'Trade associations: exploring the Trans Tasman environment for business associability,' Journal of Management \& Organization, 15(4), 404-422.

Perry, M. 2012. 'Trade associations in Ireland and New Zealand,' Irish Journal of Management, 31(2), 19-44.

Podsakoff, P., S. MacKenzie, J. Lee and N. Podsakoff 2003. 'Common method biases in behavioral research: A critical review of the literature and recommended remedies,' Journal of Applied Psychology, 88(5), 879-903. DOI: 10.1037/0021-9010.88.5.879 
Sabel, C. 1994. 'Learning by Monitoring: The Institutions of Economic Development, in The Handbook of Economic Sociology. Eds N. Smelser and R. Swedberg. Princeton, NJ: Princeton University Press.

Salisbury, R. 1984. 'Interest representation: the dominance of institutions,' American Political Science Review, 78(1), 64-76.

Storper, M. and A. Scott 2009. 'Rethinking human capital, creativity and urban growth,' Journal of Economic Geography, 9, 147-167. DOI: 10.1093/jeg/lbn052

Wren, C. and D. Storey 2002. 'Evaluating the effect of soft business support upon small firm performance,' Oxford Economic Papers, 54(2), 334-365. DOI: 10.1093/oep/54.2.334 
Table 1: Membership by association

\begin{tabular}{|c|c|c|c|c|c|}
\hline \multicolumn{6}{|c|}{ Total } \\
\hline \multicolumn{3}{|c|}{$\mathrm{N}$} & \multicolumn{3}{|c|}{$\%$} \\
\hline \multicolumn{3}{|c|}{1838} & \multicolumn{3}{|c|}{100} \\
\hline \multicolumn{3}{|c|}{ Current membership } & \multicolumn{3}{|c|}{ No current membership } \\
\hline $\mathrm{N}$ & & $\%$ & $\mathrm{~N}$ & & \\
\hline 1111 & & 60.4 & 727 & 3 & \\
\hline $\begin{array}{l}\text { Member of trade } \\
\text { association only }\end{array}$ & $\begin{array}{c}\text { Member of sector } \\
\text { association only }\end{array}$ & $\begin{array}{c}\text { Member of multiple } \\
\text { associations }\end{array}$ & Never member & Lapsed & nber \\
\hline$\%$ & $\%$ & $\%$ & $\%$ & $\mathrm{~N}$ & $\%$ \\
\hline 43.8 & 21.1 & 389 & 62.2 & 275 & 37.8 \\
\hline
\end{tabular}


Table 2: Characteristics of trade association and sector association members

\begin{tabular}{|c|c|c|c|c|c|}
\hline & \multicolumn{2}{|c|}{$\begin{array}{l}\text { Member of trade } \\
\text { association only }\end{array}$} & \multicolumn{2}{|c|}{$\begin{array}{l}\text { Member of sector } \\
\text { association only }\end{array}$} & \multirow[t]{2}{*}{$X^{2}$} \\
\hline & $\mathrm{N}$ & $\%$ & $\mathrm{~N}$ & $\%$ & \\
\hline Employment & & & & & $37.5262 * * *$ \\
\hline $0-5$ & 278 & 57.7 & 78 & 33.3 & \\
\hline $6-49$ & 193 & 40.0 & 146 & 62.4 & \\
\hline $50+$ & 11 & 2.3 & 10 & 4.3 & \\
\hline Main market & & & & & $29.356^{* * *}$ \\
\hline Local/regional & 301 & 72.2 & 102 & 50.5 & \\
\hline National & 76 & 18.2 & 72 & 35.6 & \\
\hline International & 40 & 9.6 & 28 & 13.9 & \\
\hline Sector & & & & & $56.409 * * *$ \\
\hline Manufacturing & 110 & 22.8 & 109 & 46.6 & \\
\hline Construction & 77 & 16.0 & 10 & 4.3 & \\
\hline Wholesale/Retail & 106 & 22.0 & 56 & 23.9 & \\
\hline Bus/Prop/Fin services & 58 & 12.0 & 21 & 9.0 & \\
\hline Other services & 131 & 27.2 & 38 & 16.2 & \\
\hline Location & & & & & $18.3183 * * *$ \\
\hline Urban & 334 & 71.5 & 199 & 86.1 & \\
\hline Small town/rural & 133 & 28.5 & 32 & 13.9 & \\
\hline Years business established & & & & & .543 \\
\hline Up to 5 & 19 & 4.7 & 7 & 3.4 & \\
\hline $6+$ & 388 & 95.3 & 199 & 96.6 & \\
\hline
\end{tabular}

Notes: Pearson Chi-Square with post-hoc analysis of standardised residuals $* * * \mathrm{p}<.01 ; * * \mathrm{p}<.05 ; * \mathrm{p}<.10$ 
Table 3: Business performance in the last 12 months by trade association and sector association members

\begin{tabular}{llllllll}
\hline & \multicolumn{4}{c}{$\begin{array}{c}\text { Member of trade association } \\
\text { only }\end{array}$} & \multicolumn{4}{c}{$\begin{array}{c}\text { Member of sector } \\
\text { association only }\end{array}$} & \multirow{2}{*}{$T$} \\
\cline { 1 - 6 } & $\mathrm{N}$ & $\mathrm{M}$ & $\mathrm{SD}$ & $\mathrm{N}$ & $\mathrm{M}$ & $\mathrm{SD}$ & \\
\hline Turnover & 477 & 3.08 & .960 & 233 & 2.93 & 1.044 & $3.065^{*}$ \\
Profitability & 471 & 3.12 & .946 & 232 & 3.03 & 1.010 & .524 \\
Market share & 448 & 2.88 & .654 & 226 & 2.79 & .724 & 5.492 \\
Productivity & 449 & 2.83 & .691 & 226 & 2.68 & .741 & $7.839^{* *}$ \\
\hline
\end{tabular}

Note: Likert scale $1=$ strongly increased to $5=$ strongly decreased

Student t-Test for independent samples

$* * * \mathrm{p}<.01 ; * * \mathrm{p}<.05 ; * \mathrm{p}<.10$ 
Table 4: Innovation performance in the last 12 months by trade association and sector association members

\begin{tabular}{|c|c|c|c|c|c|}
\hline & \multicolumn{2}{|c|}{$\begin{array}{l}\text { Member of trade } \\
\text { association only }\end{array}$} & \multicolumn{2}{|c|}{$\begin{array}{c}\text { Member of sector } \\
\text { association only }\end{array}$} & \multirow[t]{2}{*}{$x^{2}$} \\
\hline & $\mathrm{N}$ & $\%$ & $\mathrm{~N}$ & $\%$ & \\
\hline Product innovation & & & & & $14.835 * * *$ \\
\hline Yes & 110 & 22.6 & 85 & 18.7 & \\
\hline No & 377 & 77.4 & 150 & 81.3 & \\
\hline Process innovation & & & & & 1.443 \\
\hline Yes & 74 & 15.2 & 44 & 18.7 & \\
\hline No & 413 & 84.8 & 191 & 81.3 & \\
\hline Organisational innovation & & & & & $8.950 * * *$ \\
\hline Yes & 91 & 18.7 & 67 & 28.5 & \\
\hline No & 396 & 81.3 & 168 & 71.5 & \\
\hline Marketing innovation & & & & & $3.396^{*}$ \\
\hline Yes & 114 & 23.4 & 70 & 29.5 & \\
\hline No & 373 & 76.6 & 165 & 70.2 & \\
\hline
\end{tabular}

Notes: Pearson Chi-Square with post-hoc analysis of standardised residuals $* * * \mathrm{p}<.01 ; * * \mathrm{p}<.05 ; * \mathrm{p}<.10$ 
Table 5: Motivations for business association memberships

\begin{tabular}{|c|c|c|c|c|c|c|c|}
\hline & \multicolumn{3}{|c|}{$\begin{array}{l}\text { Member of trade } \\
\text { association only }\end{array}$} & \multicolumn{3}{|c|}{$\begin{array}{l}\text { Member of sector } \\
\text { association only }\end{array}$} & \multirow[t]{2}{*}{$T$} \\
\hline & $\mathrm{N}$ & $\mathrm{m}$ & SD & $\mathrm{N}$ & $\mathrm{M}$ & SD & \\
\hline Helps give business status & 457 & 2.24 & .942 & 207 & 2.84 & .971 & $-7.522 * * *$ \\
\hline Loyalty to industry & 459 & 2.10 & .827 & 203 & 2.82 & .923 & $-9.455 * * *$ \\
\hline Opportunity to learn from others members & 461 & 2.01 & .840 & 209 & 2.36 & .936 & $-.4662 * * *$ \\
\hline Representation to government & 450 & 2.18 & .940 & 206 & 2.40 & .898 & $-2.767 * * *$ \\
\hline Social opportunities & 457 & 2.91 & .936 & 202 & 3.00 & .949 & -1.137 \\
\hline Access to activities & 461 & 2.40 & .921 & 208 & 2.51 & .885 & -1.545 \\
\hline Access to individual advice & 462 & 2.17 & .918 & 213 & 1.98 & .887 & $2.647 * * *$ \\
\hline Opportunity to market the business & 455 & 2.51 & .936 & 206 & 2.65 & .955 & -1.722 \\
\hline
\end{tabular}

Note: Likert scale $1=$ very important to $5=$ very unimportant

Student t-Test for independent samples

$* * * \mathrm{p}<.01 ; * * \mathrm{p}<.05 ; * \mathrm{p}<.10$ 
Table 6: Benefits obtained from business association memberships

\begin{tabular}{|c|c|c|c|c|c|c|c|}
\hline & \multicolumn{3}{|c|}{$\begin{array}{l}\text { Member of trade } \\
\text { association only }\end{array}$} & \multicolumn{3}{|c|}{$\begin{array}{l}\text { Member of sector } \\
\text { association only }\end{array}$} & \multirow[t]{2}{*}{$T$} \\
\hline & $\mathrm{N}$ & $\mathrm{m}$ & SD & $\mathrm{N}$ & $\mathrm{M}$ & SD & \\
\hline Reduced business costs & 459 & 3.47 & 1.175 & 213 & 3.77 & 1.045 & $-3.294 * * *$ \\
\hline Improved ability to cope with problems & 457 & 2.96 & 1.158 & 212 & 3.01 & 1.218 & -.547 \\
\hline Improved ability to manage the business & 455 & 3.24 & 1.149 & 214 & 3.27 & 1.203 & -.303 \\
\hline Improved motivation to grow the business & 454 & 3.22 & 1.159 & 211 & 3.47 & 1.216 & $-2.519 * *$ \\
\hline Improved awareness of industry issues & 463 & 2.25 & .975 & 216 & 2.99 & 1.212 & $-7.842 * * *$ \\
\hline Improved access to customers & 457 & 3.29 & 1.112 & 213 & 3.52 & 1.084 & $-2.513 * *$ \\
\hline $\begin{array}{l}\text { Improved access to potential business } \\
\text { partners }\end{array}$ & 456 & 3.53 & 1.123 & 211 & 3.72 & 1.109 & $-2.013 * *$ \\
\hline
\end{tabular}

Note: Likert scale $1=$ very high benefit to $5=$ no benefit at all

Student t-test for independent samples

$* * * \mathrm{p}<.01 ; * * \mathrm{p}<.05 ; * \mathrm{p}<.10$ 
Table 7: Actions to increase the attractiveness of association membership

\begin{tabular}{|c|c|c|c|c|c|c|c|}
\hline & \multicolumn{2}{|c|}{$\begin{array}{l}\text { Member of } \\
\text { association only }\end{array}$} & \multirow{2}{*}{$\begin{array}{l}\text { trade } \\
\text { SD }\end{array}$} & \multicolumn{2}{|c|}{$\begin{array}{l}\text { Member of } \\
\text { association only }\end{array}$} & \multirow{2}{*}{$\begin{array}{l}\text { sector } \\
\text { SD }\end{array}$} & \multirow[t]{2}{*}{$T$} \\
\hline & $\mathrm{N}$ & $\mathrm{m}$ & & $\mathrm{N}$ & $\mathrm{M}$ & & \\
\hline Reduced cost & 468 & 2.35 & .902 & 221 & 2.47 & .917 & -1.548 \\
\hline More small firm focus & 469 & 2.01 & .768 & 224 & 2.02 & .798 & -.031 \\
\hline More influence & 458 & 2.59 & .761 & 219 & 2.84 & .760 & $-3.752 * * *$ \\
\hline Less big firm emphasis & 460 & 2.60 & .817 & 222 & 2.64 & .838 & -.389 \\
\hline More individual advice & 465 & 2.25 & .759 & 224 & 2.19 & .858 & 1.372 \\
\hline Network opportunity & 465 & 2.42 & .824 & 224 & 2.47 & .927 & -.469 \\
\hline Help to meet regulation & 465 & 2.31 & .785 & 224 & 2.49 & .903 & $-2.081 * *$ \\
\hline More government lobbying & 464 & 1.97 & .811 & 225 & 2.08 & .924 & -1.270 \\
\hline
\end{tabular}

Note: Likert scale $1=$ very important to $5=$ not important at all

Student t-test for independent samples

$* * * \mathrm{p}<.01 ; * * \mathrm{p}<.05 ; * \mathrm{p}<.10$ 
Table 8: Logistic regression results

\begin{tabular}{|c|c|c|c|c|}
\hline & $\operatorname{Exp}(\mathrm{B})$ & $\mathrm{SE}$ & Wald & p-Value \\
\hline Employment & 1.036 & .014 & 6.682 & $.010 * * *$ \\
\hline Main market: Local/regions & .856 & .461 & .114 & .735 \\
\hline Main market: National & 1.703 & .495 & 1.157 & .282 \\
\hline Sector: Manufacturing & 5.038 & .367 & 19.401 & $.000 * * *$ \\
\hline Sector: Construction & .377 & .647 & 2.273 & .132 \\
\hline Sector: Wholesale/Retail & 1.205 & .407 & .210 & .647 \\
\hline Sector: Bus/Prop/Fin services & 1.145 & .540 & .063 & .802 \\
\hline Location & 1.679 & .327 & 2.512 & .113 \\
\hline Turnover & 1.185 & .154 & 1.215 & .270 \\
\hline Productivity & .577 & .229 & 5.732 & $.017 * *$ \\
\hline Product innovation & .493 & .320 & 4.880 & $.027 * *$ \\
\hline Organisational innovation & .617 & .348 & 1.930 & .165 \\
\hline Marketing innovation & .594 & .317 & 2.691 & .101 \\
\hline Motivation: Helps give business status & 1.546 & .244 & 3.202 & $.074 *$ \\
\hline Motivation: Loyalty to industry & 2.582 & .253 & 14.108 & $.000 * * *$ \\
\hline Motivation: Opportunity to learn from other members & 1.281 & .212 & 1.366 & .243 \\
\hline Motivation: Representation to government & .623 & .210 & 5.075 & $.024 * *$ \\
\hline Motivation: Access to individual advice & .250 & .226 & 37.523 & $.000 * * *$ \\
\hline Benefits: Reduced business costs & 1.614 & .172 & 7.793 & $.005 * * *$ \\
\hline Benefits: Improved motivation to grow the business & .602 & .191 & 7.098 & $.008 * * *$ \\
\hline Benefits: Improved awareness of industry issues & 4.241 & .201 & 51.779 & $.000 * * *$ \\
\hline Benefits: Improved access to customers & .961 & .199 & .041 & .840 \\
\hline Benefits: Improved access to potential business partners & .660 & .188 & 4.851 & $.028 * *$ \\
\hline Attractiveness: More influence & 1.328 & .207 & 1.880 & .170 \\
\hline Attractiveness: Help to meet regulation & 1.217 & .200 & .966 & .326 \\
\hline Constant & .195 & 1.291 & 1.605 & .205 \\
\hline -2log likelihood & \multicolumn{4}{|c|}{374.568} \\
\hline Model chi-square & \multicolumn{4}{|c|}{$314.607 * * *$} \\
\hline Goodness of fit ${ }^{1}$ & \multicolumn{4}{|c|}{$7.853, p=.448$} \\
\hline Nagelkerke $\mathrm{R}^{2}$ & \multicolumn{4}{|c|}{.607} \\
\hline Proportional by chance hit rate $(\%)$ & \multicolumn{4}{|c|}{$58 \%$} \\
\hline Observed hit rate $(\%)$ & \multicolumn{4}{|c|}{$86 \%$} \\
\hline
\end{tabular}

Note: ${ }^{1}$ Hosmer and Lemeshow Chi-square test

$$
* * * \mathrm{p}<.01 ; * * \mathrm{p}<.05 ; * \mathrm{p}<.10
$$

